University at Buffalo School of Law

Digital Commons @ University at Buffalo School of Law

$12-5-2017$

\title{
Canadian Federalism in Design and Practice: The Mechanics of a Permanently Provisional Constitution
}

James A. Gardner

University at Buffalo School of Law

Follow this and additional works at: https://digitalcommons.law.buffalo.edu/journal_articles

Part of the Comparative and Foreign Law Commons, and the Constitutional Law Commons

\section{Recommended Citation}

James A. Gardner, Canadian Federalism in Design and Practice: The Mechanics of a Permanently Provisional Constitution, 9 Perspectives on Federalism, no. 3, at 1 (2017).

\section{(c) (1) (8)}

This work is licensed under a Creative Commons Attribution-NonCommercial-NoDerivs 2.5 Italy License. This Article is brought to you for free and open access by the Faculty Scholarship at Digital Commons @ University at Buffalo School of Law. It has been accepted for inclusion in Journal Articles by an authorized administrator of Digital Commons @ University at Buffalo School of Law. For more information, please contact lawscholar@buffalo.edu. 
ISSN: 2036-5438

Canadian Federalism in Design and Practice: The

Mechanics of a Permanently Provisional Constitution

by

James A. Gardner*

Perspectives on Federalism, Vol. 9, issue 3, 2017 


\section{Abstract}

This paper examines the interaction between constitutional design and practice through a case study of Canadian federalism. Focusing on the federal architecture of the Canadian Constitution, the paper examines how subnational units in Canada actually compete with the central government, emphasizing the concrete strategies and tactics they most commonly employ to get their way in confrontations with central authority. The evidence affirms that constitutional design and structure make an important difference in the tactics and tools available to subnational units in a federal system, but that design is not fully constraining: there is considerable evidence of extraconstitutional innovation and improvisation by governments. Furthermore, changes in practice initiated by Canadian subnational actors have produced changes in the allocation of national and subnational authority that are plausibly characterized as constitutional in magnitude. The paper concludes that the design of the Canadian federal system may inadvertently undermine its capacity to stabilize itself at any particular point of constitutional evolution, making it 'permanently provisional.'

\section{Key-words}

federalism, Canada, constitutional law, constitutional design 


\section{Introduction}

In the classic model of constitutionalism, a constitution is understood to be a permanent article of positive law containing a set of fixed instructions issued by a popular sovereign to its governmental agents. To ensure that constitutional commands issue only from the popular sovereign - to prevent the people's agents from changing their own instructions constitutions are deliberately 'entrenched.' That is, the constitution is rendered presumptively permanent by making it difficult to change, and by ensuring that the people remain the sole ultimate source of amending authority. This largely static model comports well with the philosophical premises of contractarianism, which holds that political legitimacy is founded on the consent of the governed (Locke 1690), and thus tends to conceive of a constitution as fixed and permanent - 'established in its entirety at a definite time and place' (Griffin 1996: 2124), at the moment in which consent was granted.

In sharp contrast, the constitutions of federal states are almost universally viewed as dynamic and continually evolving. Among those who study federalism, there is remarkable consensus on this point. '[F]ederal systems,' according to Arthur Benz (2008: 1), 'are highly dynamic.' 'The various parts of the system,' M.J.C. Vile (1961: 3) observes, 'are in continuous interaction.' On account of this property, Carl Friedrich (1968: 7) claimed, '[f]ederal relations are fluctuating relations in the very nature of things.' In short, according to Benz and Broschek (2013: 2), 'federal systems are permanently in motion.' Most importantly, what moves in federal systems, according to Judith Resnik (2014: 368), is the most basic, defining feature of any federal regime: 'competencies are always in motion, and in more than one direction' (emphasis added).

This evolution, moreover, takes place without popular intervention by means of formal constitutional amendment. Consequently, as Edward McWhinney (1962: 12) wrote more than a half-century ago, in all federal states there is a 'contrast between the constitution as originally written and the actual working constitution.' This contrast can be severe, and thus, in federal systems, '[t] he written constitution . . . is of limited use in explaining how the federal system works' (Erk 2006: 456).

Why does this happen? Why would constitutions of federal states depart so dramatically from the classic conception of constitutional fixity? Granted, the classic theoretical model 
tends to overstate the case for constitutional stability. More than two centuries of experience with democratically adopted constitutions have taught that constitutions are capable of evolving though mechanisms other than formal amendment - so-called 'informal' methods of constitutional change. For example, constitutions can change informally through judicial reinterpretation (Ackerman 1991). Informal constitutional change can also be driven by changes in the governance practices of constitutional officers (Gardner 2016). Some scholars argue that the forces of informal change are sufficiently strong to conclude that ' $[\mathrm{a}] \mathrm{ll}$ constitutions change continuously' (Oliver and Fusaro 2011: 424).

Even if this is correct, scholars of federalism seem nevertheless to believe that the rate and magnitude of change of federal constitutions far outstrips the degree of normal evolution in constitutions creating other kinds of states. They argue, in effect, that change - including change of core structural aspects of the constitutional scheme - is built into federal systems in ways that lack a counterpart in constitutions of nonfederal states. If true, what might explain this phenomenon?

One possible explanation - and the one I wish to explore here - has to do with the method of entrenchment employed by federal constitutions. The conventional design approach to constitutional entrenchment involves little more than erection of a highly public expectation of compliance: the popular sovereign commands and its servants obey. This relatively static command-and-control approach, however, courts a significant risk: it offers few resources to guard against a failure of obedience by government officials. James Madison called this the problem of 'parchment barriers' (Madison 1787-1788: No. 48). On Madison's account, governments are run by human beings; human beings are subject to temptation; and the accumulation of power is an attractive temptation that few officials can be expected permanently to resist. Constitutional entrenchment, Madison agreed, is necessary, but it cannot occur dependably through the mere issuance of commands.

To deal with this problem, Madison proposed a radically different solution. If political institutions are vulnerable to human ambition, Madison argued, then '[a]mbition must be made to counteract ambition' (Madison 1787-1788: No. 51). If entrenchment cannot be achieved statically, then it must be achieved dynamically, through construction of an equilibrated system in which strong forces align in well-balanced opposition. This task is accomplished through a careful division of power, undertaken against a background assumption that power holders will attempt periodically to expand their domains. At the 
same time, other power holders will have an equally predictable propensity to defend their own domains against encroachment. Such a system is highly dynamic; it creates a kind of permanent contestation among holders of official power. If the system works well, constitutional limitations on government power are entrenched by maintenance of a dynamic equilibrium at the desired design parameters (Schwartz 1989: 35; Ordeshook 1993: 204).

Federalism is such a system. By definition, a federal constitution (1) creates a national government; (2) recognizes the permanence and autonomy of subnational units; and (3) allocates to each level some measure of power (Elazar 1966). The existence and authority of the two orders of government is then made permanent through entrenchment: the federal plan 'freezes a particular allocation of authority between provinces and the center' (Levy 2014: 345). This end is achieved, however, not simply through an initial textual allocation of competencies followed by an expectation of obedience - through the creation, that is, of parchment barriers. In the Madisonian model, each level of government is endowed with powers sufficient to allow it monitor and check the abuses of the other: 'The different governments will control each other, at the same time that each will be controlled by itself (Madison 1787-1788: No. 51). Thus, the stability of the constitutional plan depends upon the capacity of each order of government to 'control' - or at least to influence and obstruct - the other. To accomplish this end, the amount of power allocated to each level of government and the reach of its authority presumably must be calibrated with some precision; an imbalance in either direction could lead to a risky accumulation of power at the national or subnational level - the very result that federalism is instituted to preclude. Thus, constitutional designers carry a heavy burden: they must carefully plot out and entrench, as the U.S. Supreme Court has said in a comparable context, a 'finely wrought and exhaustively considered' division of power ${ }^{\mathrm{I}}$ that will permit national and subnational governments to fight each other to a permanent draw.

What Madison did not and could not know, however, was that the dynamic, contestatory system he contemplated does not fully solve the problem of constitutional entrenchment due to the phenomenon of informal constitutional change. One of the most common drivers of informal constitutional change is alteration by government officials of the practices they employ in the discharge of their official duties. As Behnke and Benz (2009: 217) explain, '[c]onstitutional evolution is often initiated by unilateral action [of government officials].' In Denning's (1997: 211) formulation, these kinds of actions may properly be understood as 
'claims of power' that constitute "'moves" made by the "legislative and executive branches ... that serve as precedents for future actions." "II The establishment of precedents permitting government authority to be exercised in new ways in turn can alter the substance of the constitution's grants of authority to the actors who establish these precedents. In other words, constitutional actors can alter their own power by changing how and when they exercise it, thus initiating change in the substance of the constitutional allocation of power (Gardner 2016: 353-364).

If static methods of constitutional entrenchment are vulnerable to the problem of 'parchment barriers,' this analysis suggests that dynamic systems of constitutional entrenchment may be vulnerable to what we might call the problem of 'plastic barriers.' That is, in a dynamic system, constitutional instructions may not be overtly repudiated or ignored, but may instead undergo alteration or evolution as holders of government power constantly probe for advantage in a permanent contest over public policy.

The problem of plastic constitutional barriers is clearly presented in constitutional systems of federalism. Federalism is by nature a contestatory system in which it is anticipated that national and subnational governments will contend to secure influence and advantage (Bednar 2009: 63-85). As a result, the elements of informal constitutional change are necessarily present. First, the tools constitutional actors possess to deploy against other actors in contests over authority are by definition the tools of official practice. To the extent that the duties of officials at each level of government include monitoring and, when necessary, deploying power against the other level of government, the form that such resistance takes is inherently a mode of official practice. Second, a constitutional regime that furnishes government officials with incentives to struggle against one another provides them with incentives to prevail not merely by deploying the tools of incursion and self-defense that the constitution uncontroversially provides, but also to compete by changing the constitutional ground rules so as to develop and deploy more effective tools of contestation (Levinson 2011).

The institutionalization of intergovernmental contestation thus has the potential to place great pressure on the stability of federal regimes. 'The incentive to deviate from the division of authority,' argues Jenna Bednar (2009: 63), 'is inescapably built in to the federal structure.' Because the system contemplates that national and subnational actors will compete against each other, '[t] he constitutional allocation of competences . . . is particularly prone to 
entrepreneurial redefinition' (Broschek 2011: 548). Constitutional actors, in other words, have an incentive to 'try to shift the balance [of constitutional authority] incrementally in a direction favourable to them,' thereby inducing a form of 'authority migration' (Benz and Colino 2011: 381). When government officials become adept players of this game, 'assignments of power and competences have to be continuously renegotiated' (Benz 2008: 1).

In short, a constitutional regime that institutionalizes contestation among officials is a regime that invites unforeseeable alteration of the very aspects of the constitutional regime that contestation is meant to stabilize - the constitutional allocation of authority. Through the process of intergovernmental contestation, the location of the boundary between national and subnational authority may shift, initially as a matter of contingent fact, and eventually as a matter of constitutional reformation. Contestatory federalism, then, is a constitutional structure that seems to invite change, not only in the palette of tools and techniques that national and subnational governments deploy against one another, but also, over time, in the substantive allocation of authority among the two orders of government.

If I am correct to this point, the relevant question of constitutional design in federal states is quite different from the one that occupied Madison. My claim is that the mechanism of intergovernmental contestation deployed by federalism to stabilize constitutional allocations of power is capable simultaneously of destabilizing those very allocations; federalism, in other words, is inherently a system with the capacity to destabilize itself. If so, then a different question arises: might some federal constitutional arrangements be more stable than others? Might they incur less risk of variation from the desired distribution of competencies, and thus endure longer? This is not an idle inquiry: by one count, 27 of the 44 federations formed in the last two hundred years have failed either by breaking apart or by collapsing into a unitary state (Lemco 1991: 1). Especially in modern, ethnonational federations, maintenance of a particular allocation of authority between national and subnational governments is often a critical term of the basic constitutional bargain upon which the legitimacy of the state is founded.

The balance of this paper explores these questions through a case study of the Canadian Constitution. It begins with an overview of the Canadian Constitution, focusing on the allocation of power between the national government and the provinces contemplated by the constitutional design. It then moves on to examine how federalism is actually practiced in 
Canada, primarily by analyzing the tools and tactics deployed by Canadian provinces in moments of conflict with the central state. It also looks at the consequences of these tactics for the constitutional allocation of power. The paper concludes with some reflections on the relation between the Canadian Constitution's federal design and the stability over time of the constitutional division of authority.

\section{A case study: Canadian federalism}

\subsection{The structure of Canadian federalism}

In a celebrated double irony of unintended consequences, the Constitution of Canada was written for the express purpose of making the structure of Canadian government as different as possible from that of the United States. In this, the designers of the document succeeded, but not in a way they foresaw. Enacted at Canadian request by the British Imperial Parliament in 1867, the original Canadian Constitution was intended to create a highly centralized state with a powerful national government for the express purpose of avoiding what Canadians saw as the catastrophic failure of the decentralized U.S. Constitution, a failure that they observed at uncomfortably close range during the American Civil War. The resulting document - the British North America Act - did in fact create a powerful central government and weak provinces. Over time, however, the Canadian Constitution became something very different: a series of decisions by the Judicial Committee of the Privy Council, a British court that served as the highest judicial authority during the colonial period, reversed the polarity of the document to the point that Canada is today among the most decentralized of all federal states (Hogg 2007: " 5.3(b), (c)). Simultaneously, the United States Constitution evolved from its original design as the charter of a decentralized state with a weak central government to something that is, for many purposes and in many circumstances, very close to its polar opposite. Neither set of drafters, then, obtained what they wanted, and one of the main differences between the two constitutional cultures today is that the fact of constitutional evolution is obvious to and often welcomed by Canadians, whereas it is sometimes denied, and often regretted, by Americans. ${ }^{\text {III }}$

The structure of Canadian federalism is complex, and needs to be described in some detail. This section begins by describing the formal features established by the Canadian Constitution, and then moves on to describe the many informal institutions and practices 
that overlie the constitutional structure and account for the characteristic institutions of Canadian federalism.

\subsubsection{The formal federal structure}

The current constitution of Canada was enacted in 1982 by the British Imperial Parliament at Canadian request, and effected the 'patriation' of the constitution, the most significant step in a long and gradual - but still incomplete - process of Canadian disengagement from the British Empire and corresponding assumption of self-sovereignty. Although the Constitution Act, 1982, made a very significant change from previous constitutional documents by adding for the first time a bill of rights - the Canadian Charter of Rights and Freedoms - it left fundamentally intact the basic structure and institutions of government created under its 1867 predecessor.

Under the Canadian Constitution, national legislative power is vested in Parliament, which consists of a House of Commons and a Senate. Members of Commons are popularly elected. Senators are formally appointed by the Governor General, an official appointed by the Queen, but by long practice the Governor General makes appointments only upon recommendation of the cabinet (Hogg 2007: ' 9.5(d)). Senators serve no terms, leaving only once they reach the constitutional retirement age of 75 .

The Senate was originally intended to serve as a forum for representation of provincial interests: the Constitution Act provides that Senators shall be appointed in equal numbers from Ontario, Quebec, the Atlantic Provinces, and the Western Provinces, the traditional four regions of Canada. However, the possibility that the Senate might serve as an effective forum for subnational power was thoroughly undermined by the constitutional method of appointment. Rather than vesting the appointment of Senators in the provinces or regions themselves, the constitution vests it for all practical purposes in the federal cabinet (Hogg 2007: ' 9.5(d)), with the predictable result that the Senate is comprised of cohorts of handpicked allies of the governing party in Commons. In consequence, the Senate has historically served neither as a vehicle for the exertion of subnational influence on national power, nor even as an effective check on the national legislative power of the Commons. Indeed, when Canadians speak of Parliament they generally mean the House of Commons; like the British House of Lords on which it was modeled, the Senate is for most purposes an irrelevancy. 
In Canada, then, national politics effectively does not take place in a bicameral legislature in which one house represents national and the other subnational interests; Canadian national politics take place in a unicameral parliamentary house in which national political parties are the primary organizing institutions (Smith 2010: 92-93). With the one exception of guaranteed provincial representation on the Supreme Court of Canada - three of the nine justices must be from Quebec - formal constitutional protections for subnational interests and autonomy are found primarily not in the blueprint of national institutions, but in the constitutional allocation of powers between the national and provincial governments.

The Canadian Constitution divides the powers of government principally into those that are exercised exclusively by Parliament and those that are exercised exclusively by the provinces. Under these provisions, the federal government has exclusive power over matters such as trade and commerce, unemployment insurance, military affairs, navigation, banking, currency, and patents and copyrights. It also has power over marriage and divorce, as well as the substantive criminal law. Most importantly, the national government is granted the power 'to make Laws for the Peace, Order, and good Government of Canada' (the so-called POGG power), a provision originally intended to reserve residual power to the national level (Hogg 2007: ' 17.1). Under the constitutional principle of paramountcy, validly enacted federal laws displace conflicting provincial laws. Exclusively provincial powers include provincial fiscal affairs, hospitals, intraprovincial public works, nonrenewable resources, education, the administration of justice, and, most notably, property and civil rights.

Things have turned out to be more complicated. Most importantly, judicial decisions by the Privy Council interpreting the constitution eventually reversed the originally contemplated balance of power, in two principal ways. First, the provincial power over property and civil rights, probably originally intended to do little more than permit Quebec to retain its private civil law following confederation with English-speaking, common-law provinces, was expanded by decisions of the Privy Council to make it one of the most significant powers exercised at any level. Much of what is now widely regarded as public law - regulation of the environment, labor, health, social services - has been deemed to fall within the exclusive jurisdiction of provinces as the regulation of property (Hogg 2007: ' 21.2). Second, the national POGG power, probably intended to be of very broad scope, was construed narrowly by the Privy Council. For example, the federal POGG power was held 
inadequate to sustain federal regulation of economically significant industries of nationwide reach, relegating their regulation to the provinces, an extremely important power under contemporary economic conditions. ${ }^{\text {IV }}$

Additional complications arise from the fact that many powers have turned out to be shared. In the area of immigration, for example, the federal government has power over the admission of immigrants, but the provinces exercise authority over settlement and integration of immigrants (Banting 2012: 262-263). In the realm of criminal law, although the federal government has authority to define crimes, provincial power over the administration of justice gives them substantial influence over the course of criminal justice. Control of trade and transportation are divided along a hazy line distinguishing interprovincial from intraprovincial activity (Hogg 2007: ch. 20). The federal government has authority to negotiate treaties, but cannot unilaterally implement them when they deal with matters falling within provincial jurisdiction (Bowman 2012).

National and provincial power are further entangled under the Canadian Constitution by the constitutional commitment to 'equalization,' a system of intergovernmental income redistribution:

'Parliament and the government of Canada are committed to the principle of making equalization payments to ensure that provincial governments have sufficient revenues to provide reasonably comparable levels of public services at reasonably comparable levels of taxation (Const. Act, 1982, ' 36(2)).'

The fiscal capacity of the provinces varies dramatically, and equalization payments by the federal government help smooth out inequalities in the ability of each province to provide its citizens with the kind of public services available elsewhere in the nation. ${ }^{\mathrm{V}}$ In the Canadian context, however, equalization addresses another kind of mismatch: the mismatch between power and resources. In many issue areas, principal authority is vested in the provinces, yet it is the federal government that has greater access to the fiscal resources necessary to accomplish programmatic objectives (Simeon 1972: 146-147). Consequently, in many cases if nationally significant goals are to be accomplished, subnational power must be yoked to national funding, a task requiring intergovernmental cooperation on a broad scale.

One additional area deserves mention: the extraordinarily complex provisions for amending the constitution, a highly contentious issue in Canadian constitutional politics. 
Under the Constitution Act, 1982, the general amending rule requires that any amendment proposed by Parliament be ratified by 'at least two-thirds of the provinces that have, in the aggregate, . . a at least fifty per cent of the population of all the provinces.' ${ }^{\text {VI }}$ This is known colloquially as the 'seven-fifty formula' because it requires the approval of seven of the ten provinces having more than fifty percent of the population. Its significance, however, lies in the way it avoids giving any province a veto while at the same time ensuring that all amendments enjoy broad regional support. First, any group of seven provinces necessarily must include at least one of the four Western provinces and at least one of the four Atlantic provinces, all but eliminating the risk of outright regional exploitation. Second, the fiftypercent population threshold requires either Ontario or Quebec to be among the ratifying provinces, guaranteeing support by at least one of the major centers of wealth and population.

Complicating matters, however, is a provision that permits provinces to opt out of constitutional amendments enacted by this method: 'An amendment . . . shall not have effect in a province the legislative assembly of which has expressed its dissent thereto by resolution supported by a majority its members. ... VII The constitutional amending rules also provide that amendments relating to a small number of issues may be enacted only by unanimous approval of the provinces, and that an amendment applying to fewer than all provinces must be approved by the legislatures of those provinces to which it applies. These rules on their face establish the basis for an unusual constitutional regime of asymmetrical application. On the other hand, to the extent that non-uniform application of constitutional rules is seen by national majority coalitions as something to be avoided - generally the case outside of Quebec - the amendment rules create incentives to change the constitution by means other than formal amendment, a topic to which we shall return shortly.

\subsubsection{Canadian federalism in practice}

As Gerald Baier (2012: 79), among many others, has observed, 'Canada’s federal system features a rather large gap between the jurisdictional map of the written constitution and the actual activities of its governments.' It is therefore essential to describe some of the important informal institutions that have arisen on the constitutional landscape. I shall mention three: constitutional conventions, responsible government, and executive federalism. 
Like the British constitution that served to a great extent as its model, the Canadian Constitution is found not only in written legal texts but also in conventions of official behavior that have, through long practice and the consolidation of widespread public support and expectation, come to be regarded as having constitutional status (Hogg 2007: ' 1.10). Although the lack of any textual warrant precludes their enforcement by judicial review, constitutional principles created by convention are nevertheless observed, often strictly, mainly through the force of convention. To give a prominent example, one very important constitutional convention institutionalizes the virtual elimination of formally granted British royal power. Section 55 of the Canadian Constitution plainly states:

'Where a Bill passed by the Houses of the Parliament is presented to the Governor General for the Queen's Assent, he shall declare, according to his Discretion, ... either that he assents thereto in the Queen's Name, or that he withholds the Queen's Assent, or that he reserves the Bill for the Signification of the Queen's Pleasure.'

This provision, by its incontrovertible language, gives the Governor General a power to veto federal legislation, yet by longstanding convention that power is never exercised. The Governor General's assent to federal legislation is still required for its validity, and such consent is routinely given, but it is given on the advice of the Prime Minister and cabinet (Hogg 2007: ' 9.5(d)); the giving of royal assent has thus been reduced by convention to a ministerial task of ritual signature.

Other significant conventions apply to the operation of Canada's constitutional federalism, and indeed have contributed significantly to the undermining of the original constitutional plan for a strongly centralized state. Among these is the disappearance of the federal power of 'disallowance' of provincial legislation. Under the Canadian Constitution, the Governor General appoints Lieutenant Governors for each province. Much as the Governor General is granted the power to veto federal legislation, so the Lieutenant Governors are constitutionally granted the authority to disallow provincial legislation. Two conventions have made these provisions virtually dead letters. First, the Governor General does not exercise actual discretion in the appointment of Lieutenant Governors; he or she makes these appointments on the advice of the Prime Minister and cabinet, thereby effectively transferring to the federal government the power to disallow provincial legislation 
(Hogg 2007: " 5.3(f), 9.3). Another convention, however, restrains the federal government from exercising this authority; it was last exercised in 1943, and any attempt to use it now would likely precipitate what would surely qualify as a constitutional crisis. The result, of course, has been to grant to the provinces a kind of genuine autonomy not contemplated by the original constitutional design.

Yet another constitutional convention relating to the operation of federalism is the appointment by Prime Ministers of a cabinet that includes representatives of all the major Canadian regions - Ontario, Quebec, the West, and the Atlantic provinces. This convention was initiated by Canada's leading founder and first Prime Minister, John Macdonald, as a way to ensure high-level federal attention to sectional interests when other institutions of the newly-created constitution seemed ill-suited to serve this function (Smith 2010: 43).

By far the most important and wide-ranging constitutional convention, however, is the convention establishing 'responsible government.' Responsible government refers to the British or 'Westminster' system of parliamentary government, which Canadians have adopted. In that system, executive power is exercised not by its formal holder, the Queen, but by the Prime Minister, who is selected by the majority party or party coalition in Parliament, and his or her cabinet. The government is 'responsible' in the sense that the executive is answerable to, and must have the continuing support of, the Parliament. The system of responsible government was similarly adopted in each of the Canadian provinces, where the head of the dominant legislative party and first minister is known as the Premier.

Finally, there is the practice of 'executive federalism,' a process of policy making in which major decisions about national policy are made not in the deliberations of a broadly representative national legislature - the paradigmatic method in modern democratic states but through intergovernmental negotiations among the chief executives of the national and subnational governments. ${ }^{\text {VIII }}$ Executive federalism is not so much a constitutional convention as an institutional consequence of an unusual set of interactions among Canadian constitutional structures, both formal and conventional. It is, in Ronald Watts's (1989: 1) apt description, 'a logical dynamic resulting from the marriage of federal and parliamentary institutions.'

Three principal conditions have underwritten the rise of executive federalism in Canada. First, Canada is not merely a federal state, but one in which the provinces exercise a very substantial degree of independent power, and the ability of the federal government to 
accomplish its objectives thus often depends upon provincial cooperation. Moreover, the expansion of the scope of governmental intervention in daily life over the course of the twentieth century, in Canada as elsewhere in the West, has only increased the number of occasions on which programmatic cooperation at both levels of government is required to achieve widely desired public objectives (Simeon 1972: 3-4).

Second, Canadian national and provincial governments all employ Westminster-style parliamentary institutions. The Westminster form of government by design greatly concentrates power in the hands of the prime minister and cabinet (Watts 1989: 1). It does so by effacing any separation of legislative and executive power and placing control over both branches in the hands of the same individual - the prime minister - who simultaneously heads the executive branch and the majority party in parliament. As a result, the Canadian Prime Minister and provincial Premiers can 'deliver' their governments in a way that U.S. presidents and governors cannot (Savoie 2009: 125); ${ }^{\mathrm{IX}}$ that is, they can with considerable confidence make representations and commitments to others about what their governments will do because they exercise a very strong degree of control over what their governments will do - as the Supreme Court of Canada has observed, 'the reality of Canadian governance [is] that, except in certain rare cases, the executive frequently and de facto controls the legislature. ${ }^{\mathrm{x}}$ American chief executives, in contrast, must contend with independent and sometimes cantankerous legislatures whose cooperation they have no power to direct. Finally, because the number of Canadian jurisdictions is small - one national government, ten provincial governments, and three territorial governments - the agreement of only fourteen individuals, a very manageable number, is required effectively to make virtually any kind of national policy. Taken together, these conditions have created a system in which 'the big issues of public policy have been settled in an elaborate system of intergovernmental accommodations presided over by the first ministers' (Carty and Wolinetz 2004: 66).

\subsection{Tools and methods of subnational influence}

Having reviewed the main structures and institutions of Canadian federalism, we are now in a position to examine the concrete methods by which subnational units in Canada influence national policy and get what they want from the national government. In brief, due to the institutionalization of executive federalism, by far the most common method to which Canadian provinces resort to get their way is negotiation. So dominant is negotiation as a 
mode of intergovernmental relations that it establishes a baseline against which all other modes are conventionally perceived in most of Canada as derogations. I describe two of these below: unilateral action and the making of threats, including the threat of secession. The subsection concludes with a brief examination of modes of subnational influence that are used widely in other federal states, but play a much smaller role in Canada: exploitation of political party channels, mobilization of popular political opinion, and constitutional litigation.

\subsubsection{Negotiation and deal-making}

The emergence of executive federalism in Canada has produced a system in which major national policy decisions are made primarily through 'a process of direct negotiation between the executives of different governments' - what Richard Simeon (1972: 5) has aptly termed 'provincial diplomacy.' In this system, characterized by 'extensive consultation and negotiation on an issue-by-issue basis' (Bakvis and Tanguay 2008: 130), Canadian provinces attempt to influence the actions of the national government through bargaining.

Comprehensive multilateral negotiations. In its purest form, the intergovernmental bargaining associated with executive federalism occurs by way of collective negotiation among all fourteen heads of government. These types of proceedings may occur within the formal confines of the institutionalized and routinized First Ministers Conference (FMC); on a more ad hoc basis in the form of First Ministers Meetings called to deal with occasional crises; or, from time to time, in quiet, behind-the-scenes consultations out of the public eye (Papillon and Simeon 2004). Not all such negotiations involve the prime minister and premiers directly; many Canadian intergovernmental negotiations are handled by ministers or bureaucrats with specific portfolios acting as representatives of their governments. ${ }^{\mathrm{XI}}$ Such meetings at all levels have become so commonplace, and so much an accepted aspect of the permanent architecture of Canadian intergovernmental relations, that an elaborate administrative apparatus has evolved to support them, including the Canadian Intergovernmental Secretariat, the Intergovernmental Conference, and a wide variety of intergovernmental affairs agencies, especially at the provincial level (Pollard 1986). Together, these institutions are capable of supporting negotiations of great breadth and complexity on subjects of considerable political controversy, producing at their best 'a broad multilateral agreement, 
including common principles and goals and a broad funding structure' (Simeon and Nugent 2012: 65).

One of the most successful comprehensive intergovernmental negotiations is the Agreement on Internal Trade (AIT), a deal struck between the federal and provincial governments in 1994. ${ }^{\mathrm{XI}}$ AIT grew out of longstanding problems rooted in the awkward constitutional division between the federal and provincial governments of regulatory authority over trade and commerce. Under the Canadian Constitution, the federal government is granted exclusive authority over 'The Regulation of Trade and Commerce,' but decisions of the Privy Council and the Supreme Court of Canada narrowed its scope considerably, simultaneously expanding the authority over trade of provinces under the heading of power to regulate property. ${ }^{\mathrm{XII}}$ This division of authority then encouraged the provinces to adopt protectionist policies that limited the mobility of goods and labor, impairing national economic performance (MacDonald Commission 1985: Vol. 3, 101-135). As concerns grew that these barriers to free internal trade were harming not only Canada's domestic prosperity but its ability to compete in an increasingly global economy, intense negotiations were initiated to bypass constitutional limitations and create by mutual agreement a system of unimpeded internal trade (Doern and MacDonald 1999). The final product, the AIT, prohibits the erection of internal trade barriers, guarantees nondiscrimination in economic opportunities on the basis of origin or residency, and commits all governments to the liberalization of trade.

Another important example of multilateral negotiation is the Social Union Framework Agreement (SUFA). Reached in 1999, the SUFA agreement established a collaborative framework among the federal government and all of the provinces except Quebec - which did not in the end join the agreement - to develop and structure social programs on a basis of equality, respect for human rights, and geographical uniformity of access to social programs and services, and committed the governments to the elimination of barriers to mobility arising from residency requirements for social programs, and various other measures. ${ }^{\mathrm{XIV}}$

Bilateral negotiations. The opportunities for Canadian provinces to influence national policy by way of negotiation are not limited to comprehensive, nationwide initiatives. As Bakvis and Brown (2010: 485) observe, Canadian intergovernmental relations 'are not so much a matrix as a series of dyadic relations: of the executives of the federal government and the 
executives of the provinces and territories, together, one-by-one, or, occasionally, in regional groups.' On account of this flexibility, provinces can, and frequently have, successfully influenced national policy in their favor through bilateral negotiations with the federal government.

Sometimes bilateral negotiations can take place on a single issue of interest primarily to one or a few provinces. One well-known example is the negotiation between Ottawa and the provinces of Newfoundland and Labrador and Nova Scotia that led to what are known as the Atlantic Accords (Feehan 2009). Under the Canadian Constitution, provinces in general have exclusive authority over non-renewable natural resources located within their borders. Jurisdiction over offshore resources, however, had been less clear. When, in the 1970s, oil prices rose dramatically, settling ownership of oil deposits off the coasts of Newfoundland, Labrador, and Nova Scotia suddenly became a pressing issue. In 1984, the Supreme Court of Canada ruled that ownership of offshore oil reserves lay with the federal government. Rather than concluding the issue, however, the judicial ruling became the point of departure for lengthy intergovernmental negotiations in which the provinces took the position that the judicial ruling deprived them of something that was theirs, and for which they ought to be compensated (Feehan 2009: 176-177).

This was enough to bring the federal government to the table, and under the eventual agreements, an Offshore Petroleum Board was established as a joint federal-provincial agency to manage development of the oil resources. Provincial taxation was permitted as though the resources were provincially owned, so that the provinces were able to raise revenue from both royalties and corporate taxation. At the same time, the federal equalization formula was adjusted in favor of the two provinces. Normally, the receipt by a province of unanticipated revenue would result in an offset, or 'clawback,' of equalization payments by the federal government. Newfoundland and Labrador, and later Nova Scotia, received reprieves from operation of the clawback principle for periods of twelve and ten years, respectively (Feehan 2009: 177-183). Subsequently, complaints by other provinces, loud politicking by Newfoundland and Labrador, and changes in federal administrations, led to repeated renegotiations of the deal in the ensuing years.

Bilateral intergovernmental deal-making does not always occur in the context of issues of concern solely to specific provinces; it also can be embedded in more comprehensive negotiations among all the governments over programs intended to have nationwide reach. 
In particular, in order to reach agreements of comprehensive scope, the federal government will sometimes cut side deals with individual provinces to secure their agreement to the broader programmatic framework. For example, in order to induce agreement to the AIT by British Columbia, Alberta, Quebec, and Newfoundland, the federal government agreed during negotiations to provisions creating narrow (and frankly protectionist) exclusions for British Columbia and Alberta's export of logs, Quebec's export approval measures relating to unprocessed fish, and Newfoundland's requirement for in-province fish processing. ${ }^{\mathrm{XV}}$

Another circumstance in which bilateral deals are struck is the negotiation of provincial authority to opt out entirely from a deal reached between the federal government and the other provinces. For example, negotiations over the Canada Pension Plan in the 1960s resulted in the inclusion at the insistence of Quebec of a provision allowing provinces to opt out and then recover lost funding on their own through an abatement of the federal income tax in the province exercising the option. This arrangement - not the first of its kind authorized Quebec to 'take full responsibility for programs that in the rest of the country were managed jointly by the federal and provincial governments or even by Ottawa alone' (McRoberts 1997: 41). While opt-out provisions often are available to any province, they are frequently included because only one or two provinces express an interest in them.

Constitutional negotiations. The combination in Canada of executive federalism and a constitutional amending formula that does not require popular participation creates conditions in which Canadian intergovernmental negotiations can extend not merely to policy within the constitutional framework, but to the terms of the basic constitutional framework itself. During the mid-twentieth century, this process was both quiet and routine:

'Provincial consent was not obtained through high-profile conferences with all the players at the table and a wide range of constitutional issues on the block. On the contrary, the federal government sought each province's consent in turn for each amendment, and, with few exceptions, this consent was quietly given by provincial executives agreeing in correspondence, not by the provincial legislatures (Russell 1992: 65).'

Even when agreement to formal constitutional amendments has been impossible to obtain, intergovernmental negotiation has nevertheless from time to time produced their functional equivalent: '[f]ederal-provincial relations are often attempts to get around constitutional strictures, and in doing so they may result in de facto constitutional change' 
(Simeon 1972: 41). An example is negotiated efforts to circumvent the constitutional allocation of powers through the practice of 'inter-delegation.' The Canadian Constitution, as indicated earlier, allocates power between the federal and provincial governments in ways that are sometimes seen at both levels of government as impediments to the enactment of desired programs. Initially, the various governments sometimes attempted to get around this problem by agreeing essentially to swap powers as needed through a process of direct mutual delegation. When this plan was judicially invalidated, a different arrangement was worked out whereby the federal government delegated federal programmatic authority to provincial administrative agencies (Hogg 2007: " 14.3(a), (b)), effectuating de facto a negotiated alteration of the constitutional allocation of power.

At the limit, provincial initiatives, especially at the insistence of Quebec, have precipitated rounds of metaconstitutional politics, in which the prime minister and premiers have agreed to rewrite the Canadian Constitution in comprehensive and far-reaching ways. In 1987, an agreement - the Meech Lake Accord - was concluded in principle. That agreement would, among other things, have recognized Quebec as a 'distinct society,' given it a greater and asymmetrical role in immigration, provided each province with the power to veto constitutional amendments, and placed limits on the federal spending power (Hogg 2007: ' 4.1(c)). After an agreement had been reached but before it could be implemented, unexpected changes in political leadership in New Brunswick and Manitoba eliminated the unanimity necessary to formalize the agreed constitutional amendments (Russell 1992: 141 142). A similar process of metaconstitutional negotiation was completed in 1992, this time with the sustained unanimous support of provincial leaders, resulting in the Charlottetown Accord. In an unusual move, however, the Accord provided for popular participation in the form of a national referendum, sending to a rare, narrow defeat the outcome of intergovernmental constitutional negotiations (Lusztig 1994).

Having reviewed in some depth the baseline method by which Canadian subnational units influence national political affairs, I turn to some other tools that Canadian provinces sometimes deploy to achieve their objectives.

\subsubsection{Ignoring the federal government}

Notwithstanding the dominant norm of mutual consultation and negotiation, Canadian provinces sometimes get their way simply by ignoring the federal government altogether and 
pursuing provincial goals directly, through the direct and unmediated exercise of provincial power. This is to some extent more possible in Canada than in other federal states on account of the large measure of power constitutionally allocated to the provinces. Quebec, for example, has an elaborate provincial program of 'interculturalism' relating to the settlement and integration into French culture of immigrants (Banting 2012). In other settings, the provinces have made direct use of their powers to counteract unilateral uses of federal power of which they disapprove. For instance, some time after extensive intergovernmental negotiations produced a nationwide health insurance program, the federal government for financial reasons decided that it could not afford to continue the program at its negotiated scope, and unilaterally cut its funding. At that point, the provinces stepped up and raised the revenue necessary to continue the program in its original form (Taylor 1989).

Occasionally, however, provinces act unilaterally not to exercise power in areas of their acknowledged competence but as a kind of power entrepreneurialism meant to seize and expand their authority. A good example of this is the history of Quebec foreign policy adventurism. In 1965, Quebec claimed, on the basis of the Canadian Constitution's requirement of provincial cooperation in treaty implementation, that provinces could have their own foreign policies, and it took the first step in this direction by signing an educational agreement with France. Federal officials first became alarmed when, in a 1967 visit to Montreal, French President Charles De Gaulle during a public appearance spontaneously and to the horror of his advisors - exclaimed 'Vive le Québec libre!' Before Quebec could make any additional moves in response to De Gaulle's prodding, federal officials quickly 'rejected Québec's claims for diplomatic independence, on the grounds that national sovereignty is indivisible in international law' (Clarkson 1989). Nevertheless, consistent with Canadian norms of consultation and negotiation, they simultaneously invited the provinces to take a more active role in formulating foreign policy in areas related to their constitutional authority.

Quebec, however, pushed this principle further than Ottawa could tolerate. In 1968, Gabon invited Quebec's minister of education to an international conference of francophone nations, without consulting or notifying Ottawa. Federal officials rebuked both Quebec and Gabon, but when the same behavior was repeated, Ottawa severed diplomatic relations with Gabon in retaliation (Mahler 1994). Quebec's entrepreneurialism, however, eventually yielded a settlement it found acceptable: foreign policy in some areas was 
thereafter conducted on a cooperative basis, and the federal government agreed to permit Quebec to become directly and officially involved on its own account in some international organizations. Given the ways in which the Canadian constitutional system is capable, in time, of transmuting practice to constitutionally entrenched convention, a degree of power entrepreneurism at the provincial level seems understandable.

A final way in which provinces act by ignoring the federal government is to exclude it from interprovincial negotiations. In 2003, the premiers of the ten provinces and the territories formed the Council of the Federation $(\mathrm{COF})$, an organization similar to the more established First Ministers Conference, but without the presence of the federal government (Simeon and Nugent 2012: 67) . Motivated in part by a growing feeling that recent federal administrations were not acting in a sufficiently consultative manner, the premiers organized themselves, in their own words, because they believe it is important for provinces and territories to play a leadership role in revitalizing the Canadian federation and building a more constructive and cooperative federal system. ${ }^{\text {XVI }}$ Thus, the COF coordinates provincial policy on matters in which federal involvement is not needed, and attempts to develop consensus positions among the provinces to enable them to present a united front in collective negotiations with Ottawa.

\subsubsection{Threats}

The making of threats is the polar opposite of the Canadian default preference for intergovernmental consultation and negotiation, yet provinces have from time to time deployed this tool in efforts to get what they want. The most notable kind of threat is of course the threat of secession, a tactic deployed by Quebec periodically over the last thirty or so years. Although it has never been entirely clear how seriously Quebec's threats to secede ought to be taken, the threat of secession has been sufficient on at least two occasions to bring the federal government - and with it, the other Canadian provinces - to the bargaining table for metaconstitutional negotiations addressed mainly to accommodating Quebec's grievances in order to keep it within the dominion. After the failure of the Meech Lake and Charlottetown Accords, Quebec held an internal referendum on secession in 1995, which failed by a narrow margin (Hogg 2007: ' 4.1(c)). ${ }^{\text {XVII }}$ Since then, Quebec governments have threatened not so much to secede as to hold another referendum on secession. This occurred most recently in the Fall of 2012, when the Parti Québécois took control of the Quebec 
parliament on a platform that included a pledge to hold such a referendum, a threat it did not carry out.

Unlike the United States, where subnational threats to engage in minor acts of defiance are often enough to get the attention of the national government, in Canada the availability of the secession threat seems to have helped create a context in which public threats of lesser disobedience are seen as insufficiently powerful to call attention to provincial grievances, especially given the ready availability of private, civil, and often meaningful bilateral negotiations with the federal government. As a result, other provinces have occasionally hinted at the possibility that they, too, might contemplate secession. Some Newfoundland premiers, for example, have found it expedient to invoke the threat of secession. In the 1970s, Premier Frank Moores raised eyebrows elsewhere in Canada by occasionally using slogans such as 'masters in our own house' (evoking the Québécois nationalist slogan maîtres chez. nous) and 'Vive Terre Neuve Libre' (Marland 2010: 161). More recently, Premier Danny Williams ordered Canadian flags removed from provincial buildings. Williams's tactics did indeed produce results in the form of a renegotiation of the Atlantic Accords. Rhetoric in Alberta has also occasionally flirted with threats to secede.

\subsubsection{Other tools of subnational influence}

Several other informal tools of influence that often receive heavy usage by subnational units in other federal states are invoked either infrequently or not at all by Canadian provinces. One such tool that is strikingly unavailable to Canadian provinces is the ability to exercise influence at the national level through the medium of political parties. ${ }^{\text {XVIII }}$ In many federations, subnational officials can call upon fellow partisans in the national legislature to press their interests. This is all but impossible in Canada due to the extreme decentralization and fluidity of Canadian political parties: although national and provincial parties were more integrated in the past, today 'Canadian parties, and the party systems they constitute, are now largely disconnected' (Carty and Wolinetz 2004: 302-303). As a result, Canadian parties do not offer paths of political influence that cross constitutional lines of authority; indeed, the centralization of power associated with the Westminster system intensifies the autonomy of national and regional or provincial parties because under that system, a minority party in a province has no standing to approach the central government, even if it is controlled by the same party (Simeon 1972: 31). ${ }^{\text {Ix }}$ Some idea of the degree to which Canadian national and 
provincial parties fail to align can be gleaned from the career of Jean Charest, who after service as a cabinet minister in the Conservative government of Brian Mulroney and a career as leader of the federal Progressive Conservative Party - the opposition party to Jean Chrétien's federal Liberals during the 1990s - went on to become the leader of Quebec's Liberal Party and Premier of the province.

In addition, Canadian parties have long adhered to a tradition of forming minority governments rather than negotiating their way into majority coalitions (Bakvis and Tanguay 2008: 130). As a result, a national party with a regional base in one or a few provinces typically cannot use the occasion of formation of a national government to extract concessions regarding subnational interests as a condition of joining a coalition government.

Another extraconstitutional tactic of subnational influence that is used very infrequently by Canadian provinces is mobilization of popular opinion. ${ }^{\mathrm{xx}}$ Although it has been tried occasionally, most notably by Newfoundland Premier Danny Williams to generate pressure on Ottawa to renegotiate bilateral deals concerning revenue from natural resources, it does not seem an especially effective tactic. One reason may be a Canadian political culture that stresses respectful consultation over dramatic confrontation, but another may be simply that Canadian politics is not highly democratic in the sense of cultivating broad popular involvement - the so-called 'democratic deficit' (Bakvis and Skogstad 2002: 19).

Finally, despite the availability of a widely respected constitutional court with a power of judicial review and a demonstrated willingness to elaborate the boundaries of constitutional powers, Canadian provinces over the last three decades have rarely resorted to litigation to get what they want from the federal government. At one time this was a relatively common tactic; as Russell (1992: 97) reports, between 1975 and 1982, the Supreme Court of Canada decided some eighty constitutional cases dealing with the allocation of power. Judicial rulings were subsequently shown, however, to be weak constraints on power because of the ability of federal and provincial officials to negotiate quasi-constitutional or even formal constitutional changes. ${ }^{\mathrm{xxI}}$ Furthermore, '[i]n Canada, . . . frequent recourse to the courts is sometimes seen as an indicator of breakdown of these more consensual, administrative mechanisms' (Simeon 2000: 148). Consequently, intergovernmental agreements of the kind described earlier have largely eclipsed the courts as the institutional vehicle for assigning power (Baier 2012: 86-91). 


\section{Conclusions: The Impact of Constitutional Design on Federal Stability}

Unlike subnational units in many federal states, Canadian provinces have ready access to extremely powerful tools to influence national policy and actions, including negotiated alteration of the federal constitution itself. As a result, they do not need to resort to improvised weaker tools, as is often the case elsewhere (Gardner 2005: 87-98; Gardner and Abad 2011). The availability of such tools makes Canadian provinces potentially extremely effective advocates of provincial interests in the arena of national policy making. Nevertheless, this provincial effectiveness may come at a price to the extent that it results from what might be called the 'hyperplasticity' of the Canadian Constitution's allocations of federal and provincial power.

By hyperplasticity in this context, I mean that the capacity of provinces to elevate policy disputes with Ottawa to the level of constitutional disputes - to convert negotiations over policy into negotiations over the constitutional allocation of national and provincial powers - seems to create an incentive structure in which governments have significant incentives to raise the stakes in every negotiation. In this environment, policy disagreements between the provincial and federal government carry inherently the potential to serve as an opening for constitutional dispute, and the constitution therefore need not be seen by the players as establishing a set of binding institutional structures and constraints within which other decisions are taken. Instead, governments engaged in conflict may be tempted to view the constitution as provisional and subject to renegotiation whenever it seems to offer them a losing position. If you are going to lose in a policy dispute conducted according to a particular set of rules, why accept the rules if they can be changed mid-negotiation? If the constitution allocates a power to the national level and the national government will not exercise that power in a way congenial to a province, why should a province hold out for its policy preference when it can instead press for a reallocation of the power in question to the provincial level? In these circumstances, the practice of intergovernmental relations has a distinct tendency to collapse into pure, unconstrained politics. ${ }^{\text {XxII }}$ Constitutional flexibility, of course, has its benefits; the ability of Canadian governments to negotiate their way past constitutional obstacles has 'on many occasions ... allowed constitutional rigidities to be 
circumvented' (Bakvis and Skogstad 2002: 8). But it may be possible for this fluidity to go too far. As Marc-Antoine Adam has observed,

\begin{abstract}
'what is striking with Canadian federalism is that we try to govern this country without the assistance of a legal framework, i.e., the Constitution. ... That we should constantly be negotiating is perhaps normal; that there should be no permanent agreed-upon rules to govern our negotiations and what we negotiate is more troublesome. But this is what a constitution is meant to provide: a set of fundamental rules or a framework within which the day-to-day political process can take place. Lack of agreement on day-to-day political issues is normal and healthy. Lack of agreement on the fundamental rules is a different matter. In fact, one could say that in our federation, because of this lack of agreed-upon fundamental rules, the management of what should be day-to-day political issues has a tendency to mutate into quasiconstitutional negotiations, with the ironical result that Canada, for wanting to avoid its constitution, finds itself locked in a state of permanent constitutional debate' (Adam 2009: 297-298).
\end{abstract}

Moreover, as Choudhry (2003: 78) notes, the fact that Canadian governments prefer to settle their disputes through judicially unenforceable intergovernmental agreements instead of through, say, the creation of mutually binding statutory law, suggests an underlying preference for remaining at all times completely free and unbound, just as states are in international diplomacy.

Federal constitutions do not attempt to preserve the state by suppressing conflict. Quite to the contrary, federal constitutions begin from the premise that intrasocietal conflict is inevitable and neither can nor should be suppressed. Instead, federal constitutions seek to preserve the stability of the state by creating a forum in which, if all goes well, conflict can emerge predictably and safely - the forum of intergovernmental contestation. In that, the Canadian Constitution has succeeded: conflict between the provinces and the central government is frequent and open, and the arena of intergovernmental contestation has become by far the most important and the most flexible forum within which policy conflicts among Canadians are resolved.

Yet it is by no means clear that the forces aligned in opposition during intergovernmental conflict are balanced in a way that achieve a Madisonian equilibrium revolving reliably around a politically consensual center of constitutional gravity. The design of the Canadian Constitution has encouraged the emergence of negotiation as the dominant mechanism by 
which intergovernmental contestation is waged. Yet that same design has not been successful in containing the scope of such negotiations within the parameters fixed by the constitution. If the success of a federal state is measured by the robust endurance of a mutually agreeable division of authority among the orders of government, the Canadian Constitution may be guilty of purchasing short-term peace at the expense of long-term risk to constitutional stability. * Bridget and Thomas Black SUNY Distinguished Professor, University at Buffalo School of Law, State
University of New York. An earlier version of this paper was presented at a Symposium on the Constitution
of Canada at Scuola Sant'Anna, Pisa, Italy, on May 24, 2017. I thank the organizers for their kind invitation and
the participants for useful comments. The research on which this paper is based was undertaken principally in
the fall of 2012, while I served as Fulbright Visiting Research Chair in the Theory and Practice of
Constitutionalism and Federalism at McGill University. I thank Fulbright Canada for its support, and the
members of the McGill Research Group on Constitutional Studies, most especially its director, Jacob Levy, for
support and illuminating conversation during the period of my fellowship.

I INS v. Chadha, 462 U.S. 919, 951 (1983).

II Denning here quotes John R. Vile, Encyclopedia of Constitutional Amendments, Proposed Amendments, and Amending Issues, 1789-1995 (1996), at 92.

III This distinction is perhaps most clearly manifest in the Supreme Court of Canada's embrace of the 'living tree' doctrine of organic constitutional evolution compared to the U.S. Supreme Court's adoption of originalism as the preferred mode of constitutional interpretation.

IV A.G. Canada v. A.-G. Alta. (Insurance Reference), [1916] 1 A.C. 588; Hogg, 2007: ' 17.4(a).

$\checkmark$ Recently, only two provinces - Ontario and Alberta - have been net resource exporters. All the other provinces receive equalization payments from Ottawa. Hogg 2007,' 6.6.

VI Constitution Act, 1982, ' 38(1)(b).

VII Constitution Act, 1982, ' 38(3).

VIII As one commentator has put it, "[i]n Canada, intergovernmental relations have become the substitute for engagement through Parliament' (Smith 2010: 93). See also Russell (1992: 81): 'By the mid 1960s meetings of federal and provincial ministers and their expert advisers on virtually all topics became so numerous that they were supplanting legislatures as the primary arena of Canadian policy making.'

Ix Savoie (2009: 115-119) argues that the Canadian Prime Minister has an even stronger hand than most prime ministers in Westminster systems on account of a recent consolidation of executive power by the Harper Government in the hands of the prime minister at the expense of the cabinet. In his view, Canada's national government is developing into a modern version of monarchical court government in which ' $[a] d v i s o r s$, much like courtiers of old, have influence, not power' (130).

x Wells v. Newfoundland, [1999] 3 S.C.R. 199, \& 54.

XI Simeon's (1972) analogy to international diplomacy has great traction here: just as in the international realm, Canadian intergovernmental relations may be carried on by heads of state, or by progressively lower-level officials, depending upon the degree of interest and involvement governments wish to convey, consistent with diplomatic conventions.

$$
\text { XII Available }
$$

https://www.cfta-alec.ca/wp-content/uploads/2017/06/Consolidated-with-14th-Protocol-final-draft.pdf. ${ }_{\text {XIII E.g., A.-G. Canada v. A.G. Alta. (Insurance Reference) [1916] } 1 \text { A.C. 588; The King v. Eastern Terminal }}$ Elevator Co. [1925] S.C.R. 434; A.-G. B.C. v. A.-G. Can. (Natural Products Marketing Reference) [1937] 2 S.C.R. 151.

xIv A Framework to Improve the Social Union for Canadians, available at http://www.scics.gc.ca/english/conferences.asp?a'viewdocument\&id'638. For contemporaneous analysis and critique, see, e.g., Lazar 2000 and Young 1999.

xv AIT, supra note XII, Annex 1102.3.

xvI Council of the Federation, http://www.councilofthefederation.ca/aboutcouncil/aboutcouncil.html.

xVII The vote was $50.6 \%$ against separation and $49.4 \%$ in favor. 
XVIII Compare the descriptions of party channels of influence in the United States and Spain in Gardner and Abad (2011: 508-509).

XIX Chhibber and Kollman (2004) attribute this to the strong decentralization of power in the system, i.e., because the provinces have such significant responsibility, voters have incentives to vote their policy preferences at the provincial level; whereas in more centralized systems they have incentives to vote their national preferences in subnational elections.

xx Such tactics are used effectively elsewhere - in Spain, for example. Gardner and Abad (2011: 509-510). Cf., however, Wright (2016: 29), claiming that 'Public criticism of federal initiatives by the provinces is a staple of intergovernmental politics in Canada.' Wright later goes on to cast doubt on the efficacy of this tactic as a means by which provinces might discipline the national government (36-44).

XxI Swinton (1990: 10-20) describes the court's decisions as only an early move in what is often a series of strategic actions by provincial governments. Ryder (2006: 353) similarly describes 'a familiar pattern in Canadian federalism' in which an initial victory in court by the central government is followed by the losing province being 'accommodated politically through intergovernmental negotiations.' Scholars, moreover, seem to agree that the Supreme Court has in recent years backed away from an aggressive form of judicial review of structural issues, preferring instead to let the political branches work out their disagreements through negotiations (Wright 2010; Ryder 2006; Brouillet 2006).

xxII Choudhry (2003: 82) argues that the 'site for the evolution of the legal framework governing social policy has been in politics. The politics of social policy, in other words, has been an arena for constitutional politics.'

\section{References}

- $\quad$ Ackerman Bruce, 1991, We the People: Foundations, Harvard University Press, Cambridge, Mass.

- Adam Marc-Antoine, 2009, 'Fiscal Federalism and the Future of Canada: Can Section 94 of the Constitution Act, 1867, Be an Alternative to the Spending Power?', in Allan John R., et al. (eds), Canada: The State of the Federation, 2006/7: Transitions: Fiscal and Political Federalism in an Era of Change, McGill-Queen's University Press, Montreal.

- Bakvis Herman and Brown Douglas, 2010, 'Policy Coordination in Federal Systems: Comparing Intergovernmental Processes and Outcomes in Canada and the United States,' Publius, XL(3): 484-507.

- Bakvis Herman and Skogstad Grace, 2002, 'Canadian Federalism: Performance, Effectiveness, and Legitimacy,' in Bakvis Herman and Skogstad Grace (eds), Canadian Federalism: Performance, Effectiveness, and Legitimacy, Oxford University Press, Don Mills, Ontario.

- Bakvis Herman and Tanguay A. Brian, 2008, 'Federalism, Political Parties, and the Burden of National Unity: Still Making Federalism Do the Heavy Lifting?,' in Bakvis Herman and Skogstad Grace (eds), Canadian Federalism: Performance, Effectiveness, and Legitimacy, $2^{\text {nd }}$ ed., Oxford University Press, Oxford.

- Banting Keith G., 2012, 'Remaking Immigration: Asymmetric Decentralization and Canadian Federalism,' in Bakvis Herman and Skogstad Grace (eds), Canadian Federalism: Performance, Effectiveness, and Legitimacy, $3^{\text {rd }}$ ed., Oxford University Press, Don Mills, Ontario.

- Bednar Jenna, 2009, The Robust Federation, Cambridge University Press, Cambridge.

- Behnke Nathalie and Benz Arthur, 2009, 'The Politics of Constitutional Change between Reform and Evolution,' Publius, XXXIX(2): 213-240.

- Benz, Arthur, 2008, 'German Dogmatism and Canadian Pragmatism? Stability and Constitutional Change in Federal Systems,' (unpublished paper), Institut für Politikwissenschaft, FernUniversität in Hagen, polis Nr. 65/2008, at 1 .

- Benz Arthur and Broschek Jörg, 2013, 'Federal Dynamics: Introduction,' in Benz Arthur and Broschek Jörg (eds), Federal Dynamics: Continuity, Change, and the Varieties of Federalism, Oxford University Press, Oxford.

- Benz Arthur and Colino César, 2011, 'Constitutional Change in Federations - A Framework for Analysis,' Regional and Federal Studies, XXI(4/5): 381-406.

- Bowman Gregory W., 2012, 'U.S. and Canadian Federalism: Implications for International Trade Regulation,' West Virginia Law Review, CXIV: 1007-1052.

- Broschek Jörg, 2011, 'Conceptualizing and Theorizing Constitutional Change in Federal Systems: Insights from Historical Institutionalism,’ Regional and Federal Studies, XXI(4/5): 539-559. 
- Brouillet Eugénie, 2006, 'The Federal Principle and the 2005 Balance of Powers in Canada,' Supreme Court Law Review (2 $\left.{ }^{\text {nd }}\right)$, XXXIV: 307-333.

- Carty R. Kenneth and Wolinetz Steven B., 2004, 'Political Parties and the Canadian Federation's Coalition Politics,' in Meekison J. Peter, et al. (eds), Canada: The State of the Federation, 2002: Reconsidering the Institutions of Canadian Federalism, McGill-Queen's University Press, Montreal.

- Chhibber Pradeep K. and Kollman Ken, 2004, The Formation of National Party Systems: Federalism and Party Competition in Canada, Great Britain, India, and the United States, Princeton University Press, Princeton.

- Choudhry Sujit, 2003, 'Beyond the Flight from Constitutional Legalism: Rethinking the Politics of Social Policy Post-Charlottetown,' Forum Constitutionnel, XII(3): 77-83.

- Clarkson Stephen, 1989, 'Vive le Québec Libre! Putting the Leader Back In,' in Shugarman David P. and Whitaker Reg (eds), Federalism and Political Community: Essays in Honour of Donald Smiley, Broadview Press, Petersborough, Ontario.

- Denning Brandon P., 1997, 'Means to Amend: Theories of Constitutional Change,' Tennessee Law Review, LXV: 155-244.

- Doern G. Bruce and MacDonald Mark, 1999, Free-Trade Federalism: Negotiating the Canadian Agreement on Internal Trade, University of Toronto Press, Toronto.

- $\quad$ Elazar Daniel, 1966, American Federalism: A View From the States, Thomas Y. Crowell, New York.

- Erk Jan, 2006, "Uncodified Workings and Unworkable Codes": Canadian Federalism and Public Policy,' Comparative Political Studies, XXXIX: 441-462.

- Feehan James P., 2009, 'Equalization 2007: Natural Resources, the Cap, and the Offset Payment Agreements,' in Allan John R., et al. (eds), Canada: The State of the Federation, 2006/ 7: Transitions: Fiscal and Political Federalism in an Era of Change, McGill-Queen's University Press, Montreal.

- $\quad$ Friedrich Carl J., 1968, Trends of Federalism in Theory and Practice, Pall Mall Press, London.

- Gardner James A., 2005, Interpreting State Constitutions: A Jurisprudence of Function in a Federal System, University of Chicago Press, Chicago.

- Gardner James A., 2016, 'Practice-driven Changes to Constitutional Structures of Governance,' Arkansas Law Review, LXIX: 335-369.

- Gardner James A. and Abad i Ninet Antoni, 2011, 'Sustainable Decentralization: Power, Extraconstitutional Influence, and Subnational Symmetry in the United States and Spain,' American Journal of Comparative Law, LIX: 491-527.

- $\quad$ Griffin Stephen M., 1996, 'The Problem of Constitutional Change,' Tulane Law Review, LXX: 2121-2168.

- Hogg Peter W., 2007, Constitutional Law of Canada (2 vols.), Thomson Canada, Scarsborough, Ontario.

- Lazar Harvey, 2000, The Social Union Framework Agreement: Lost Opportunity or New Beginning?, Institute of Intergovernmental Relations, School of Policy Studies, Queen's University, Kingston, Ontario.

- Lemco Jonathan, 1991, Political Stability in Federal Governments, Praeger, New York.

- Levinson Daryl J., 2011, 'Parchment and Politics: The Positive Puzzle of Constitutional Commitment,' Harvard Law Review, CXXIV: 657-746.

- $\quad$ Levy Jacob T., 2014, 'The Constitutional Entrenchment of Federalism,' in Fleming James E. and Levy Jacob T. (eds), Nomos LV: Federalism and Subsidiarity, New York University Press, New York.

- Locke John, 1952 (orig. ed. 1690), Thomas P. Peardon (ed), Second Treatise of Government, Bobbs-Merrill, Indianapolis, Indiana.

- Lusztig Michael, 1994, 'Constitutional Paralysis: Why Canadian Constitutional Initiatives Are Doomed to Fail,' Canadian Journal of Political Science, XXVII(4): 747-771.

- MacDonald Commission, 1985, Report of the Royal Commission on the Economic Union and Development Prospects for Canada (3 vols), Minister of Supply and Services Canada, Ottawa.

- $\quad$ Madison James, et al., 1787-1788, The Federalist.

- Mahler Gregory S., 1994, 'Quebec and Foreign Policy: Overseas Options for a Province in a Federal System,' Quebec Studies, XVII: 59-74.

- Marland Alex, 2010, 'Masters of Our Own Destiny: The Nationalist Evolution of Newfoundland Premier Danny Williams,' International Journal of Canadian Studies, XLII: 155-181.

- McRoberts Kenneth, 1997, Misconceiving Canada: The Struggle for National Unity, Broadview Press, Petersborough, Ontario. 
- McWhinney Edward, 1962, Comparative Federalism: States' Rights and National Power, University of Toronto Press, Toronto.

- Oliver Dawn and Fusaro Carlo (eds), 2011, 'Towards a Theory of Constitutional Change', in How Constitutions Change: A Comparative Study, Hart Publishing, Oxford.

- $\quad$ Ordeshook Peter C., 1993, 'Some Rules of Constitutional Design,' in Frankel Ellen, et al. (eds), Liberalism and the Economic Order, Cambridge University Press, Cambridge.

- Papillon Martin and Simeon Richard, 2004, 'The Weakest Link? First Ministers' Conferences in Canadian Intergovernmental Relations,' in Meekison Peter, et al. (eds), Canada: The State of the Federation, 2002: Reconsidering the Institutions of Canadian Federalism, McGill-Queen's University Press, Montreal.

- Pollard Bruce G., 1986, Managing the Interface: Intergovernmental Affairs Agencies in Canada, Queen's University Press, Kingston, Ontario.

- Resnik Judith, 2014, 'Federalism(s)' Forms and Norms: Contesting Rights, De-essentializing Jurisdictional Divides, and Temporizing Accommodations,' in Fleming James E. and Levy Jacob T. (eds), Nomos LV: Federalism and Subsidiarity, New York University Press, New York.

- $\quad$ Russell Peter H., 1992, Constitutional Odyssey: Can Canadians Be a Sovereign People?, University of Toronto Press, Toronto.

- $\quad$ Ryder Bruce, 'The End of Umpire? Federalism and Judicial Restraint,' Supreme Court Law Review (2 $\left.{ }^{\text {nd }}\right)$, XXXIV: 346-377.

- $\quad$ Savoie Donald J., 2009, 'Power at the Apex: Executive Dominance,' in Bickerton James and Gagnon Alain-G. (eds), Canadian Politics (5th ed.), University of Toronto Press, Toronto.

- Schwartz Thomas, 1989, 'Publius and Public Choice,' in Grofman Bernard and Wittman Donald (eds), The Federalist Papers and the New Institutionalism, Agathon Press, New York.

- Simeon Richard, 1972, Federal Provincial Diplomacy: The Making of Recent Policy in Canada, University of Toronto Press, Toronto.

- Simeon Richard, 'Adaptability and Change in Federations,' International Social Science Journal, LIII: 145152.

- Simeon Richard and Nugent Amy, 2012, 'Parliamentary Canada and Intergovernmental Canada: Exploring the Tensions,' in Bakvis Herman and Skogstad Grace (eds), Canadian Federalism: Performance, Effectiveness, and Legitimacy ( $3^{\text {rd }}$ ed.), Oxford University Press, Don Mills, Ontario.

- $\quad$ Smith David E., 2010, Federalism and the Constitution of Canada, University of Toronto Press, Toronto.

- Swinton Katherine E., 1990, The Supreme Court and Canadian Federalism: The Laskin-Dickson Years, Carswell, Toronto.

- Taylor Malcolm G., 'Health Insurance: The Roller-Coaster in Federal-Provincial Relations,' in Shugarman David and Whitaker Reg (eds), Federalism and Political Community: Essays in Honour of Donald Smiley, Broadview Press, Petersborough, Ontario.

- $\quad$ Vile M.J.C., 1961, The Structure of American Federalism, Oxford University Press, Oxford.

- Watts Ronald L., 1989, Executive Federalism: A Comparative Analysis, Queens University Institute of Intergovernmental Relations, Kingston, Ontario, available at http://www.queensu.ca/iigr/sites/webpublish.queensu.ca.iigrwww/files/files/pub/archive/researchpapers/ Researchpaper26ExecutiveFederalismWatts.pdf.

- Wright Wade K., 2010, 'Facilitating Intergovernmental Dialogue: Judicial Review of the Division of Powers in the Supreme Court of Canada,' Supreme Court Law Review (2 $\left.{ }^{\text {nd }}\right)$, 51: 625-693.

- Wright Wade K., 2016, 'The Political Safeguards of Canadian Federalism: The Intergovernmental Safeguards,' National Journal of Constitutional Law, XXXVI:1-71.

- $\quad$ Young Margot, 1999, 'The Social Union Framework Agreement: Hollowing Out the State,' Constitutional Forum X: 120-128. 